\begin{tabular}{|l|l|l|}
\hline \multicolumn{2}{|c|}{ PublisherInfo } \\
\hline \hline PublisherName & $:$ & BioMed Central \\
\hline \hline PublisherLocation & $:$ & London \\
\hline \hline PublisherImprintName & $:$ & BioMed Central \\
\hline \hline
\end{tabular}

\title{
Controlling the bacterial cell cycle
}

\begin{tabular}{|l|l|l||}
\hline \multicolumn{2}{|c|}{ ArticleInfo } \\
\hline \hline ArticleID & $:$ & 3868 \\
\hline \hline ArticleDOI & $:$ & $10.1186 /$ gb-spotlight-20001218-02 \\
\hline \hline ArticleCitationID & $:$ & spotlight-20001218-02 \\
\hline \hline ArticleSequenceNumber & $:$ & 305 \\
\hline \hline ArticleCategory & $:$ & Research news \\
\hline \hline ArticleFirstPage & $:$ & 1 \\
\hline \hline ArticleLastPage & $:$ & 2 \\
\hline \hline & $:$ & RegistrationDate : 2000-12-18 \\
ArticleHistory & $:$ & OnlineDate $\quad$ 2000-12-18 \\
\hline \hline ArticleCopyright & $:$ & BioMed Central Ltd2000 \\
\hline \hline ArticleGrants & $:$ & \\
\hline \hline ArticleContext & $:$ & 130591111 \\
\hline \hline
\end{tabular}




\section{William Wells}

Email: wells@biotext.com

In the 15 December Science, Laub et al. find that a full 19\% of the genome of the bacterium Caulobacter crescentus is subject to cell-cycle-specific regulation (Science 2000, 290:2144-2148). A surprising number of genes are induced, as in yeast, just before they are needed. Other genes, such as those directing the construction of the flagella and pilus, are induced in transcriptional cascades, with the order of induction reflecting the order of assembly of the respective apparatus. Laub et al. also use their microarray to determine the effect of decreasing or increasing the function of the CtrA response regulator. Temporal and spatial regulation of CtrA are vital for the differentiation and cell cycle progression of Caulobacter cells, and Laub et al. find that 26\% (144 of 553) of all cell-cycle-dependent transcripts are directly or indirectly affected by CtrA levels. Candidates for the other important cell cycle regulators in Caulobacter include 27 newly identified temporally controlled genes encoding twocomponent signal transduction proteins and sigma factors.

\section{References}

1. Science, [http://www.sciencemag.org/]

2. A genome-wide transcriptional analysis of the mitotic cell cycle. 